Abstracta Iranica

Revue bibliographique pour le domaine irano-aryen

Volume 32-33 | 2013

Comptes rendus des publications de 2009-2010

\title{
Caroline Waerzeggers. The Ezida Temple of Borsippa. Priesthood, Cult, Archives
}

\section{Astrid Nunn}

\section{(2) OpenEdition}

1 Journals

\section{Édition électronique}

URL : http://journals.openedition.org/abstractairanica/40438

DOI : 10.4000/abstractairanica.40438

ISSN : 1961-960X

Éditeur :

CNRS (UMR 7528 Mondes iraniens et indiens), Éditions de l'IFRI

\section{Édition imprimée}

Date de publication : 1 décembre 2013

ISSN : 0240-8910

\section{Référence électronique}

Astrid Nunn, "Caroline Waerzeggers. The Ezida Temple of Borsippa. Priesthood, Cult, Archives ", Abstracta Iranica [En ligne], Volume 32-33 | 2013, document 130, mis en ligne le 01 juillet 2016, consulté le 28 septembre 2020. URL : http://journals.openedition.org/abstractairanica/40438 ; DOI : https://doi.org/10.4000/abstractairanica.40438

Ce document a été généré automatiquement le 28 septembre 2020.

Tous droits réservés 


\title{
Caroline Waerzeggers. The Ezida Temple of Borsippa. Priesthood, Cult, Archives
}

\author{
Astrid Nunn
}

\section{RÉFÉRENCE}

Caroline Waerzeggers. The Ezida Temple of Borsippa. Priesthood, Cult, Archives. Leiden, NINO, 2010, 803 p. (Achaemenid History XV)

1 Parmi les innombrables textes provenant des fouilles illicites de Borsippa au XIX ${ }^{\text {e }}$ s. 224 textes inédits, conservés en grande partie au British Museum et datant d'environ 750 à 484 av. J.-C. forment le noyau de cette étude. Ceux-ci illustrent l'administration quotidienne de l'Ezida, temple principal de Borsippa. Cette étude est divisée en deux parties. La vie des prêtres, des familles et des prébendes, des brasseurs, des boulangers et des bouchers de l'Ezida, les revenus, les coûts et les taxes ainsi que les cultes et les fêtes sont commentés dans la première partie (362 pages). Le soin des dieux, duquel dépendait leur bien-être, était fondamental pour la survie du pays. Les textes nous décrivent donc la préparation des repas, la fabrication, le nettoyage et la réparation des vêtements divins et la maintenance de l'habitation divine. Dans la seconde partie les textes sont édités. Un CD ROM avec la photo de presque tous les textes accompagne ce livre qui est une source inépuisable sur le fonctionnement, les structures sociales, économiques et religieuses d'un grand temple babylonien au milieu du $\mathrm{I}^{\mathrm{er}}$ millénaire aussi bien que sur le vocabulaire accadien de cette époque. 


\section{AUTEURS}

\section{ASTRID NUNN}

Université de Munich 